\title{
Changes of the Employment Structure in the Tourism Sector and Further Tendency of E-Tourism in Hungary
}

\author{
Noémi HajdúA, Katalin Lipták ${ }^{B *}$ \\ Received: September 2017 | Accepted: September 2017 \\ DOI: 10.5937/turizam21-16111
}

\begin{abstract}
The study will analyzes and compare changes of the employment in two different years (2008 and 2013) in Hungary NUTS 2 level regions. The labor market of these NUTS 2 level regions had an influence of the economic crisis lately and the most of states have not yet recovered from the deep recession. Even though the employment policies were introduced significant$l y$, the labor market was affected negatively by the crisis. The calculation of difference analysis is solved by using shift-share analysis on regional levels of Hungary. A shift-share analysis determines the relationship between economic growth indicators and other national or regional factors. The analysis helps to identify regional sectors which have competitive advantages. A shift-share analysis takes account of the employment changes over time among industries of a regional economy. Then it classifies the employment changes into various components. The relationship between the tourism employment and the other sectoral employment will be illustrated.We analyzed the problem which is so called "20-80 societies" and occurred by the impact automation processes.
\end{abstract}

Key Words: world economic crisis, shift-share analysis, employment structure, e-tourism

\section{Introduction}

The study was focused on the employment structure changes and e-tourism changes. We assume that the economic crisis of 2008 affected not only the tourism sector but also the consumer habits. The online business trend has changed the consumer habits globally as people has started to make well informed decisions. In 2015 the online retail sales reached the amount of HUF 319 billion which is the $4.1 \%$ of the domestic retail sales (eNET). The change of consumer habits has impacted the tourism sector as well. The extension of the internet access over the

A University of Miskolc, Faculty of Economics, Institute of Marketing and Tourism, H-3515 Miskolc, Egyetemváros, mail: margn@uni-miskolc.hu

B University of Miskolc, Faculty of Economics, Institute of World-and Regional Economics, H-3515 Miskolc, Egyetemváros

* Corresponding author: liptak.katalin@uni-miskolc.hu 
world has changed the consumer habits globally. It has influenced the information availability, the decision making process and the shopping attitude. According to Peterson and Merino (2003), this popularity derives from the perceived usefulness of the service which means fast, easy and efficient access to information. A number of factors can influence the process of searching and understanding of information and finally its effect on buying. It includes the internet usage, digital skills and the consumer habits in online environment. It may sound unusual to analyze the relationship between the employment structure changes and the consumer habits. But it could be interesting if there is a close relationship between the two areas.

\section{The importance of tourism in Hungary}

Nowadays the tourism is one of the world's largest economic sector which contributes $3.1 \%$ of the direct GDP growth or USD 7.6 trillion in amount and 292 million jobs in 2016 (WTTC, 2017). It is interesting that the performance of this sector contributes to the GDP in higher amount than the average in Hungary, as its the value is $4.1 \%$ (WTTC, 2017).

The tourism enhances the economic performance due to the consumption from the tourism can impact positively the labour market. Kaspar-Fekete (2006 in: Kardos, 2011) distinguished four economic functions, regarding the tourism sector, which are production and income function (value creation), balance of payment function, employment function and equalization function.

New economic value can be generated by tourism products and services. Newly issued service package offers and new jobs can contribute to the economic growth of the industrial sector and further more economy of the country. The value creation in tourism sector has an effect on other sectors of the economy, too. Inbound and outbound tourisms are included in the current account. In 2016 - according to the Hungarian National Bank's report - the trade including the tourism services contributed with EUR 938 million to the asset of the current account (Elöd, 2017). It means that inbound tourism is stronger than outbound tourism in Hungary.

The balancing function occurs at regional level in where the effect of tourism on the labor market is principal. More underdeveloped areas and regions - with their natural attractiveness, sport centres and rural tourism - can be joined to the circulation and helped to catch-up (ex. Northern Hungarian or Northern Great Plain regions). For the economically underdeveloped regions in Hungary, the strengthening of the tourism sector may mean a catch-up or at least it may increase the cash inflow in regions (Wirth, 2016).

In accordance with the data of 2016, the $6 \%$ of total Hungarian employees or 266 ooo people work in the tourism sector. Thus, the effect of the tourism on the labour market is vital. The sector employs unskilled seasonal labour in a large amount. The data of the following table shows the Hungarian tourism sector's effect on the total employment and its contribution to the total GDP.

Table 1. Hungary's tourism significance in figures

\begin{tabular}{|l|c|c|c|c|c|c|c|c|c|c|}
\hline & 2007 & 2008 & 2009 & 2010 & 2011 & 2012 & 2013 & 2014 & 2015 & 2016 \\
\hline $\begin{array}{l}\text { GDP of tourism } \\
\text { (\% of whole economy GDP) }\end{array}$ & 3.6 & 3.9 & 4.2 & 4.1 & 4.1 & 4.0 & 3.8 & 3.9 & 4.0 & 4.1 \\
\hline $\begin{array}{l}\text { Employment of tourism } \\
\text { (\% of whole economy employment) }\end{array}$ & 5.0 & 5.5 & 5.8 & 5.7 & 5.9 & 5.8 & 5.3 & 5.5 & 5.7 & 6.0 \\
\hline
\end{tabular}

Source: Own editing based on WTTC data 
The number of foreign and domestic guest nights increased steadily between 2008 and 2016. The effect of the economic crisis could be realised between 2008 and 2011 due to the stagnation of the guest numbers. However since 2012 there has been a significant increase in the tourism as there was the end of crisis and the households saved on holidays and travels during the beginning time of the income scarcities.

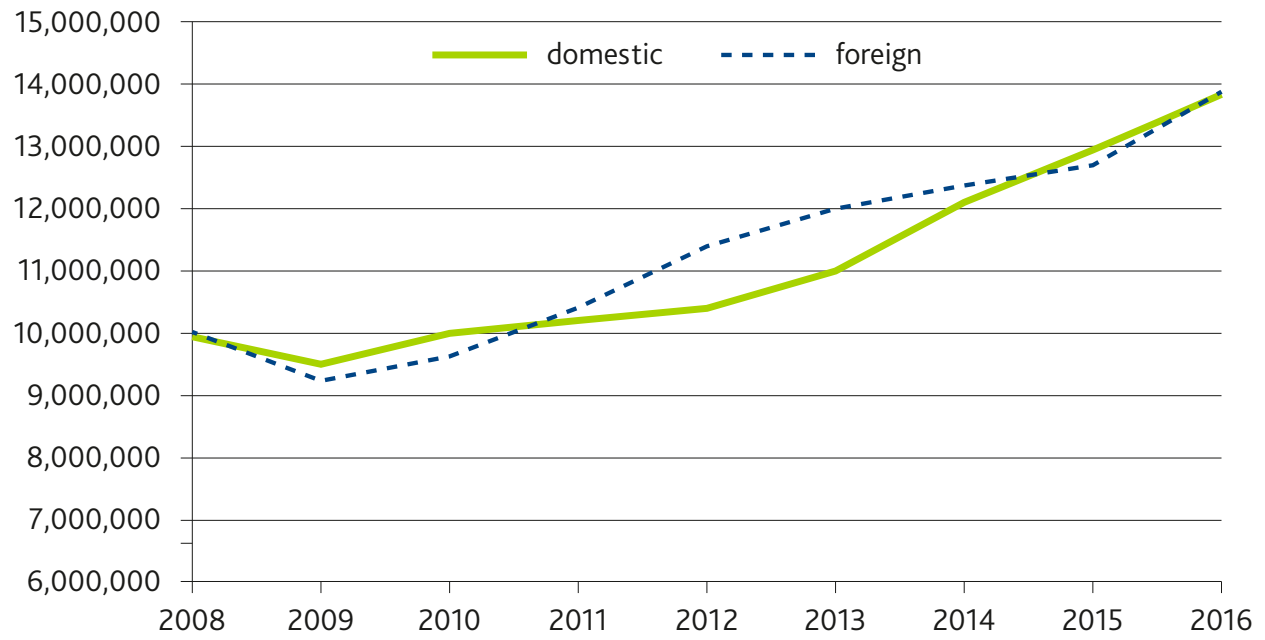

Figure 1. The number of night spent by residents and non-residents in Hungary (2008-2016) Source: Own editing based on WTTC data

\section{Evaluation of changes in the employment structure - methodology}

In order to define the employment positioning of the Hungarian regions, the employment data were used. It is interesting to analyze the shift which happened in the employment sector between the outbreak year of economic crisis (2008) and the economic recovery year (2013). The impact proportion analysis or so called "the shift-share analysis", suitable for classifying factors of regional economic growth, were made for the calculations.

The methodology is briefly described:

Let $\mathrm{X}_{\mathrm{ij}}$ be the number of employees in sector $\mathrm{i}$ in the $\mathrm{j}$ unit and at the initial time, and $\mathrm{X}_{\mathrm{ij}}^{\prime}$ at the final point of the analysis. So, the difference between the two values can be written as follows:

$X_{i j}^{\prime}-X_{i j}=X_{i j}=X_{i j} g+X_{i j}\left(g_{i}-g\right)+X_{i j}\left(g_{i j}-g_{i}\right)$

where

$$
g=\frac{\sum_{i=1}^{s} \sum_{j=1}^{r}\left(X_{i j}^{\prime}-X_{i j}\right)}{\sum_{i=1}^{s} \sum_{j=1}^{r} X_{i j}} g_{i}=\frac{\sum_{j=1}^{r}\left(X_{i j}^{\prime}-X_{i j}\right)}{\sum_{j=1}^{r} X_{i j}} g_{i j}=\frac{X_{i j}^{\prime}-X_{i j}}{X_{i j}} t
$$


Shift-share analysis assign components of the growth of phenomena into categories.

- all effect (or national effect)

Explains, the extent of how the full employment has increased at local level (in the $\mathrm{j}$ territorial unit) due to the national economic growth during the examined period.

- regional effect (or local effect)

Emphasized on the level of the territory unit which ones are the leader sectors and which ones are the lagging sectors. It compares the growth rate of the given sector at local level, with the growth rate of the same sector at national level; determining whether the given area unit has a competitiveness advantage in one of the sectors. The leading sector at the level of the regional unit is where the local growth rate of the sector is higher than the national growth rate.

- sectoral effects (or sectoral effects)

Based on the national growth of the different sectors, it shows fast or slow increase happened during the examined period in the given area unit.

The total effect: $\mathrm{L}_{\mathrm{ij}}=\mathrm{EN}_{\mathrm{ij}}+\mathrm{ES}_{\mathrm{ij}}+\mathrm{ER}_{\mathrm{ij}}$ marks the increase of the area unit.

Nemes Nagy (2005) aggregated the effects according to their signs and shift directions and defined 8 categories (Table 2), that are in our calculations.

Table 2. Evaluation categories of shift-share analysis

\begin{tabular}{|c|c|c|c|c|c|}
\hline Nr. & Categorie & $\begin{array}{l}\text { National effect } \\
\text { (EN) }\end{array}$ & $\begin{array}{l}\text { Regional effect } \\
\text { (ER) }\end{array}$ & $\begin{array}{l}\text { Sectoral effect } \\
\text { (ES) }\end{array}$ & $\begin{array}{l}\text { The relation of } \\
\text { the magnitude of } \\
\text { the factors }\end{array}$ \\
\hline 1. & \multirow{2}{*}{$\begin{array}{l}\text { Greater change than average } \\
\text { Positive regional factor } \\
\text { Positive structural factor }\end{array}$} & + & + & + & $E R>E S$ \\
\hline 2. & & + & + & + & $E R<E S$ \\
\hline 3. & $\begin{array}{l}\text { Greater change than average } \\
\text { Negative regional factor } \\
\text { Positive structural factor }\end{array}$ & + & - & + & $|E R|>|E S|$ \\
\hline 4. & $\begin{array}{l}\text { Greater change than average } \\
\text { Positive regional factor } \\
\text { Negative structural factor }\end{array}$ & + & + & - & $|E R|<|E S|$ \\
\hline 5. & $\begin{array}{l}\text { Smaller change than average } \\
\text { Negative regional factor } \\
\text { Positive structural factor }\end{array}$ & - & - & + & $|E R|>|E S|$ \\
\hline 6. & $\begin{array}{l}\text { Smaller change than average } \\
\text { Positive regional factor } \\
\text { Negative structural factor }\end{array}$ & - & + & - & $|E R|<|E S|$ \\
\hline 7. & \multirow{2}{*}{$\begin{array}{l}\text { Smaller change than average } \\
\text { Negative regional factor } \\
\text { Negative structural factor }\end{array}$} & - & - & - & $E R>E S$ \\
\hline 8. & & - & - & - & $E R<E S$ \\
\hline
\end{tabular}

Source: Nemes Nagy (2005) refers to Péter (2010:32) 


\section{Evaluation of the changes in the employment structure-results}

In case of Hungary there was no regional data on the number of people employed in tourism, NACE classification was taken as a base. The number of people employed in tourism can be found In the groups of wholesale, retail, transport, accommodation and catering.

In 2008, the total number of employees was 409000 people in the North-Hungarian region; in 2013 it decreased to 400800 people (a decrease of $2 \%$ ). The number of the employees in each sector was the following in 2008 (Table 3) 15.300 people in the agriculture and forestry, 116700 people in the industry, 38700 people in the construction industry, 100800 people in the field of trade and hospitality, 4500 people in the field of information and communication, 7600 people in the financial sector, 97600 people worked in the public administration sector. The number of the employees in the North Hungarian region decreased to 2013, which is contrary to the data of the Hungarian data. In Hungary the number of the employees increased by 58900 people to 2013 (growth could be observed in the Central-Hungarian, Southern Great Plain and the Northern Great Plain regions). Between the sectors, the most significant growth in the number of employees happened in the field of agriculture, information and communication, and public administration in a national context.

Table 3. Number of employees in the Northern-Hungarian region (people)

\begin{tabular}{|c|c|c|c|}
\hline $\begin{array}{l}\text { NACE code } \\
\text { (Statistical Classification of Economic Activities in the European Community) }\end{array}$ & 2008 & 2013 & $\begin{array}{l}\text { Change to } \\
2013\end{array}$ \\
\hline Agriculture, forestry, fishing & 15300 & 20700 & 5400 \\
\hline Industry (without construction industry) & 116700 & 119500 & 2800 \\
\hline Construction industry & 38700 & 23800 & -14900 \\
\hline Wholesale and retail trade, transport, accommodation and catering & 100800 & 86600 & -14200 \\
\hline Information and communication & 4500 & 3200 & -1300 \\
\hline Financial and insurance activities & 7600 & 5500 & -2100 \\
\hline Real estate affairs & n.a. & n.a. & n.a. \\
\hline Professional, scientific, technical activities; administrative and service support activities & 16800 & 17000 & 200 \\
\hline Public administration, defence, education, human health and social care & 97600 & 114000 & 16400 \\
\hline Art, entertainment, leisure; other services & 11000 & 10500 & -500 \\
\hline
\end{tabular}

Source: own editing based on Eurostat data

The result of the shift-share calculation shows (Table 4.) that the decrease dynamics of the data of employment rate of the North - Hungarian region, is less than the national value (14292 people employees assuming the national growth rate); of which there are components derives from the structure of the sector (19613 people employed). In the comparison among the regions, a large proportion of the positive values of all effects (national effect, EN) appeared in Central Hungary, Southern Transdanubia, and Northern Great Plain. On the contrary, the lagging behind the national level was the highest appeared in the largest proportion in Central Hungary and Northern Hungary. 
Table 4. Shift-share analysis according to the number of employees in the employment sectors (2013/2008)

\begin{tabular}{|c|c|c|c|c|c|c|c|}
\hline NACE code & 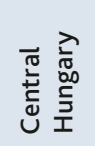 & 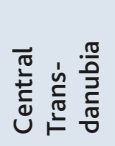 & 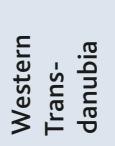 & 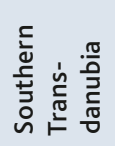 & 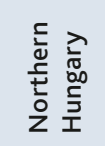 & 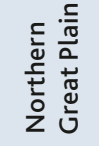 & 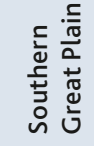 \\
\hline Agriculture, forestry, fishing & -315 & -3734 & 1993 & 3786 & 2978 & -261 & -4445 \\
\hline Industry (without construction industry) & 4669 & -6083 & -13259 & 3820 & 4767 & 6091 & -6 \\
\hline Construction industry) & 836 & 28900 & 28600 & 23500 & 23800 & 35200 & 31500 \\
\hline $\begin{array}{l}\text { Wholesale and retail trade, transport, } \\
\text { accommodation and catering }\end{array}$ & 10316 & 4274 & 3315 & -1106 & -10732 & -6530 & 463 \\
\hline Information and communication & -879 & 712 & -1250 & 1775 & -2038 & 2014 & -334 \\
\hline Financial and insurance activities & 2486 & -70 & 244 & -1907 & -2270 & -2199 & 3715 \\
\hline Real estate affairs & 4852 & 0 & -2380 & 0 & 0 & -2472 & 0 \\
\hline $\begin{array}{l}\text { Professional, scientific, technical activities; } \\
\text { administrative and service support activities }\end{array}$ & 5553 & -5167 & 2368 & -1791 & -2500 & 2088 & -551 \\
\hline $\begin{array}{l}\text { Public administration, defence, education, } \\
\text { human health and social care }\end{array}$ & -7652 & -2871 & -3351 & 6337 & 5487 & 10431 & -8381 \\
\hline Art, entertainment, leisure; other services & -1659 & 1222 & 3280 & -251 & 121 & -2486 & -226 \\
\hline EN (national effect) & 23728 & -16214 & -10827 & 9315 & -14292 & 10758 & -2468 \\
\hline ER (regional effect) & 18205 & 17184 & 19560 & 34163 & 19613 & 41876 & 21735 \\
\hline ES (sectoral effect) & 5523 & -33398 & -30387 & -24848 & -33905 & -31118 & -24203 \\
\hline
\end{tabular}

Source: own editing based on Eurostat data

The calculation results are illustrated on a map in the case of the 7 Hungarian regions based on the worked out categories by Nemes Nagy (2005). In the case of the regions, the territorial effect prevailed more strongly in the case of Central Hungary, Southern Transdanubia and Northern Great Plain regions; the sectoral effect prevailed more strongly in the rest of the regions.

In Hungary, the importance of the tourism sector has been strengthened since the economic crisis, but the development of tourism and the number of people working in tourism still need to be increased. Nowadays, the consumer behaviour "takes the life easy" as increas-

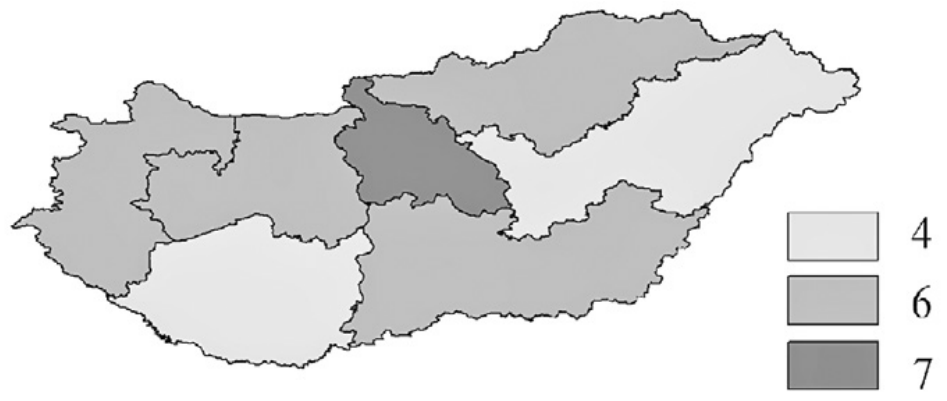

Figure 2. Shift-share analysis results (based on the classification categories in Table 1)

4: greater change than average, positive regional factor, negative structural factor

6: smaller change than average, positive regional factor, negative structural factor

7: smaller change than average, negative regional factor, negative structural factor

Source: own editing based on own calculations 
ingly applying online tools. This attitude also affects the tourism as the most rooms are being booked by online. Below is an overview about the impact of automation on the tourism sector.

\section{The impact of automation on the tourism sector}

From the beginning of $21^{\text {st }}$ century, travel customs have being changed significantly. Information source revolution and new technologies have a significant role for this change. According to the wide available information sources on the internet, travellers can plan a trip, book an accommodation, compile different programs and compare different offers. According to the wide available information sources on the internet, travellers can plan a trip, book an accommodation, compile different programs and compare different offers.

We agreed with Antonioli and Baggio (2011 in: Sekulovic, 2015), who claimed that "the information technologies improved the business process of tourism offer". The booking process has been accelerated, because the advantages caused by the relevant online information. These advantages can be accessibility, reliable information, personalization, interaction, and security according to No and $\operatorname{Kim}(2015,272)$ who identified "five attributes of online tourism information sources through a factor analysis".

Not surprisingly, according to the Eurostat (2016) most of the accommodations are booked online, in Hungary in 2014 this data was $64,7 \%$, while the average of EU-28 without UK is $54,8 \%$. The rate is not so high in case of transport booking for the trip, in EU-28 it is $23.6 \%$, while in Hungary it is only $7 \%$. There is no statistical information available, but in our opinion this $7 \%$ mostly means flight tickets booking, but of course railway and bus transport also in it.

Accordingly, the Eurostat (2016) internet use related to travel is 39\% of population in EU-28. The question arises that how the online automata word will affect the numbers of people employed in tourism. Activities regarding tourism can be differentiated the following way, activities where the human presence is necessary and booking processes that can be automated. On the one hand, in the initial information gathering processes, like asking and comparing the prices, the different holiday packages and programs, services, are automatic. But on the other hand, human resource is still needed in tourism and this branch probably will always be overrepresented in this regard. There will always be a demand for human work connected to for example room service, catering, entertaining, fitness and wellness programs. However, there will be transitions where both human resource and robots will be applied, such as guided tours. Let's think it over, when a virtual guided tour in hotels, museums, cities in the chosen language removes the language barriers and the holiday becomes more interesting and valuable. So the answer is complex for the above mentioned question.

We believe that one of the elements of meeting the rapidly growing consumer expectations lies in the application of smart technologies, which is not necessarily associated with increasing employment. In the literature, this concept has been read for decades. As the impact of globalization and automation on the labour market, the concept of $20-80$ societies can be found in the literature reviews more often (Schumann, 1998; Rifkin, 1995; Almási, 1998). According to this view, in the future it is expected to be enough $20 \%$ employment in the entire population to hold the world economy in motion. Almási (1998) agrees: since capital and money have become mobilized, the loss must be suffered by the labour market...today's capitalism could work well with $20 \%$ of the people currently employed - the rest is not needed. This is the utopia of (unworking) society. Martin-Schumann's statement is quite extreme, it has reality content, but we do not think it is so significant. 


\section{Summary, proposals}

In the study it was analyzed that the economic crisis in 2008 in the Hungarian regions affected not only to the changes in the employment structure but also to the e-tourism. As a result of the crisis, consumers became more aware of their expenditures for their trips. Consumer habits have changed, due to information availability on the internet, a program planning and booking an accommodation came into the foreground. Tourism's effect on the economy is significant because of its contribution to GDP and economic value creation. The underdeveloped regions can develop and catch up with the developed areas by establishing tourist destinations, offering new service package and creating job positions. Based on the results of the calculations, the increase in the number of people employed in tourism in the most underdeveloped Northern Hungary region can be justified, especially considering the latest tendencies. Due to seasonal characteristic of the tourism, the forms of the atypical employment (ex. part-time work, fixed-term contracts) would be the most favourable solution for both the employee and employers. Online business trend has a significant impact on the tourism. It has changed the travelers habit completely in last few years. The market of tourism has being transferred from the traditional way of doing business to online business.

We suppose that the concept of the $20-80$ society will be affected by the tourism sector in the future, but this is a natural consequence of the development process.

\section{References}

Almási, M. 1998. Üveggolyók - az ezredvég globális játszmái?, Helikon Kiadó, Budapest, 173.

Antonioli, C. M., Baggio, R. 2011. Internet \& Turismo 2.o Milano, Egea.

Előd, F. 2017. Felhúzta a turizmus az ország fizetési mérlegét.

http://index.hu/gazdasag/2017/o3/23/felhuzta_a_turizmus_az_orszag_fizetesi_merleget/ Accessed: 2017.05.17.

eNET 2016. Minden 25. forintot a neten költenek el a magyarok. http://www.enet.hu/hirek/ minden-25-forintot-a-neten-koltenek-el-a-magyarok/ Accessed: 2017.05.07.

Eurostat 2016. Statistics on ICT use in tourism.

http://ec.europa.eu/eurostat/statistics-explained/index.php/Statistics_on_ICT_use_in_tour-

ism\#Over_1_in_3_internet_users_bought_or_ordered_travel_related_services_online Accessed: 17.10.2017

Kardos, Z. 2011. Turisztikai ismeretek- Egyetemi tankönyv, Keszthely.

www.tankonyvtar.hu/hu/tartalom/tamop425/o034.../desztinacio-marketing.pdf Accessed: 2017.05.17.

Kaspar, C., Fekete, M. 2011. Menedzsment a turizmusban. Távoktatási tankönyv, Budapest https://issuu.com/mutf/docs/turizmusmenedzsment Accessed: 17.05.2017

Martin, H.P., Schumann, H. 1998. A globalizáció csapdája: Támadás a demokrácia és a jólét ellen, Perfekt Kiadó, Budapest, 352

Nemes Nagy, J. 2005. Regionális elemzési módszerek, Regionális Tudományi Tanulmányok 11, 284

No, E., Kim, J. K. 2015. Comparing the attributes of online tourism information sources. Computer sin Human Behaviour 50, 564-575.

Péter, Zs. 2010. A turizmus térségi folyamatainak összefüggései, különös tekintettel az Észak-magyarországi régióra, Ph.D. értekezés, Miskolc, 180. 
Peterson, R. A., Merino, M. C. 2003. Consumer information search behavior and the internet. Psychology \& Marketing 20(2), 121-13.

Rifkin, J. 1995. The end of work - The Decline of the Global Labor Force and the Dawn of the Post-Market Era, Tarcher/Putnam, New York.

Sekulovic, N. 2015. Trends and New Initiatives in Tourism at the Time of the General Economic Crisis and the Current Situation in Serbian Tourism. Procedia Economics and Finance 23 (2), 1628-1634.

Wirth, G. 2016. Historical Review of the Tourism Development of Lake Velence. International Scientific Journal Turizam 2o(4), 192-211.

World Travel \& Tourism Council 2017. Travel \& Tourism Economic Impact 2017, Hungary.

https://www.wttc.org/-/media/files/reports/economic-impact-research/countries-2017/hungary2017.pdf Accessed 17.05.2017 